\title{
The Political and Social Conflict between Orthodox Christianity (Constantinople and Rome) and Eastern Monophysitism
}

\begin{abstract}
By Jayoung Che
The 4th Ecumenical Council of Chalcedon (431) denounced Eutychianism/Monophysitism as a heresy. Rushdoony suggested that the Chalcedonian formula made Western liberty possible because the unity and particularity (or individuality) firmly grounded in the triune God freed man from the oppression of the state. In my opinion, however, even the triune God does not always refer to everybody's liberty, but could degenerate into an instrument protecting the privileged. The so called universalism exploited by some Byzantine emperors or most senatorial aristocrats refers to the enforcement of the religious dogma; the former preferred Monophysitism for consolidating autocratic imperial power, and the latter the Chalcedonian formula for securing their liberty against the emperors' despotism. Enforcing whichever kind of religious dogma denotes the degeneration of the Byzantine Society towards an exclusive, privileged society. Contrary to religious exclusivism, there was a type of Christianity which was more universal and openminded, not only towards heretics but even to the pagans.
\end{abstract}

\section{Introduction}

As Constantine the Great promulgated the Edict of Milan (313 AD), the Hellenic-Roman traditions and the various sects of Christianity began to coexist legally. Actually, however, the universalism of Christianity allowed it to open its mind towards the so called pagans and the Christians took part in the traditional pagan cults without any hesitation, while at the same time the movement of orthodox exclusivism against heterodoxies began to rise.

First of all Arianism ${ }^{1}$ was denounced as a heresy by the $1^{\text {st }}$ Ecumenical Council of Nicea in 325 under Constantine the Great, later Apollinarism in 381 by the $1^{\text {st }}$ Concil of Constantinople, Nestorianism by the $3^{\text {rd }}$ Ecumenical Council of Ephesus (431), Nestorianism and Eutychianism (Monophysitism) [or Dioscorus, Patriarch of Alexandria condemned ${ }^{2}$ ] by the 4 th Ecumenical

\footnotetext{
*Assistant Professor, Busan University of Foreign Studies, Republic of Korea.

1. Refer to Glossary of Terms which is attached at the end of the paper, between the Conclusion and the Bibliography, for comprehending technical terms related to the religious sects.

2. Cf. Fr. Matthias F. Wahba, "Monophysitism: Reconsidered," < Monophysitism and the Council of Chalcedon, 6 >, St. Antonius Coptic Orthodox Church Hayward, California, USA, accessed December 13, 2014, http://bit.ly/1KOewTZ.
} 
Council of Chalcedon (451), Monophysitism by the Fifth Ecumenical Council of Constantinople (553) under Justinian the Great, and Monotheletism (God with one will) ${ }^{3}$ by the $3^{\text {rd }}$ Council of Contantinople (678). Arianism and Nestorianism gave much weight to the human nature of Christ, while Apollinarism, Eutychianism (Monophysitism), and Monotheletism to the divinity. It is the latter which was supported now and then by the Byzantine emperors, which came into conflict with Orthodox Christianity.

Eutyches, a presbyter at Constantinople, founded the base of Monophysitism which it spread into the Eastern countries, Egypt, Palestine and Syria and Armenia in the 5th Century, resulting in conflict with the Orthodox Church of the Byzantine Empire and Rome. In the $5^{\text {th }}$ and $6^{\text {th }}$ centuries the Byzantine emperors' religious inclinations alternated between Orthodoxy and Monophysitism. Especially, the religious views of Justinian the Great were not coherent at first glance. Justinian stuck to Orthodoxy on principle, but now and then he tried to win Monophysites over to his side. And the Empress Theodora, an Egyptian by origin, actually supported Monophysites. S. Patoura-Spanou suggested regarding the inconsistency of the religious policy under the reign of Justinian the Great, that the Byzantine Empire made good use of every kind of religious sect to expand its influences toward the provinces. ${ }^{4}$

In my opinion, however, the religious inclination of each emperor altered according to the purpose and method of governing the Empire. For example, sustaining or rejecting Monophysitism resulted in different effects on the relationships between emperors and capital or provincial aristocrats, the Byzantine Empire and the people of the provinces, and the Eastern and Western Orthodox Churches. This paper is to review the political and social meaning of the discord around Monophysitism in the earlier period of the Byzantine Empire. My argument is that, regardless of Orthodoxy and Monophysitism, the exclusive dogmatism contributed to the interest of either the prerogatives of aristocrats or the emperor's dictatorial domination. Contrary to religious exclusivism, there was a Christianity which was more universal and open-minded, even towards the pagans.

\section{The Theoretical Difference between Orthodoxy and Monophysitism and its Social Significance}

Nicea (325) and Constantinople (381) put an end to the major controversy over the immanent Trinity, rejecting the Arianian and modalistic understanding of the Trinity. ${ }^{5}$ Arianism purported that Jesus Christ was not God. He was a

3. Cf. Monophysitism was modified to Monotheletism (God with one will) and Monoenergetism (God with one function) under the Heracleian Dynasty in the $7^{\text {th }}$ century.

4. S. Patoura-Spanou, Christianismos kai pagkosmiotita sto Proimo Byzantio: Apo tin Theoria stin Praxi [Christianity and Globality in Early Byzantium: From theory to Practice] Athina: Ethniko Idryma Ereunon, Instituto Byzantinon Ereunon (2008), 121.

5. Cf. Seumas Macdonald, "The importance of the Monophysite and Nestorian controversies," <Introduction and Prolegomena>, <1. The Christological controversies>, accessed December 1, 2014, http://bit.ly/1iLI6iG. 
created being, the very first creation, and everything else in creation was created by Him and through Him. The Council of Nicea and that of Constantinople affirmed that the Christ was of the same essence as the Father. ${ }^{6}$ The two heresies, Nestorianism and Monophysitism that arise afterwards are orthodox in the understanding of the immanent Trinity, but their error is found in their understanding of the relationship between the humanity and divinity of Christ.

The $4^{\text {th }}$ Ecumenical Council of Chalcedon defined Christ as one person (hypostasis) with two natures (physeis: human and divinity). According to Orthodox Christianity, Jesus is of one personality consisting of two properties which are connected with one another without being mixed and in harmony without being contradictory. These two natures are united but distinct; one but two: unconfused, indivisible, inseparable [but united].

Differing from Orthodoxy, it is Docetism that lurks in the background of Eutychianism/ Monophysitism, which avoids the humanity of Christ, a topdown Christology. Jesus only appeared to be human, but He in fact was not. Eutyches' Monophysitism (Eutychianism) denies both Jesus' true humanity and true deity, and regards the Humanity of Christ as being absorbed by His Divinity, as if a drop of honey had fallen into the sea. ${ }^{7}$

Monophysitism emerges not as a parallel and opposite heresy to Nestorianism, but a subsequent and reactionary heresy. Nestorius rejecting the term, "theotokos" for Maria, sets up a descent that will lead to Mary bearing only the human physis. ${ }^{8}$ When Nestorius becomes Nestorianism, the two physeis are held apart so that there are two persons. ${ }^{9}$ In the view of the Orthodox Church, both Nestorianism and Monophysitism are ineffective for mediation between God and men. In Nestorianism, a divided mediator cannot mediate himself, let alone God and Humanity, and in Monophysitism, the Christ is a fusion of the two pre-incarnate physeis, and it will be neither homoousios with us in humanity nor homoousios with the Father in godhead.

Monophysitism itself can be seen as the final product of the Alexandrian school. ${ }^{10}$ Monophysites, who spread widely in the Eastern countries, Syria including Antiochia, Palestine, Mesopotamia and Egypt with Alexandria, denied the decision of the Council of Chalcedon. It is worth keeping in mind

6. Seumas Maconald, "The importance of the Monophysite and Nestorian controversies", $<1$. The Christological controversies $>$.

7. H.A. Wolfson, The Philosophy of the Church Fathers (Cambridge, Mass.: Harvard U.P., 1956), 600.

8. Seumas Maconald, "The importance of the Monophysite and Nestorian controversies," $<1$. The Christological controversies >. Nestorius opposed Arianism, as well as any idea that the Divine Logos was created. He refused to the use of "Theotokos," meaning "a creatrix" rather than "genetrix".

9. Seumas Macdonald, "The Importance of the Monophysite and Nestorian controversies for Christology ", <1. The Christological controversies>.

10.Alexandrian theology traces its methodology back to Philo, and his allegoricalphilosophical interpretation of the Old Testament. And Origen takes this on-board and develops it in a Christian manner. Cf. Seumas Macdonald, "The importance of the Monophysite and Nestorian controversies," <1. The Christological controversies>. 
that in fact, the doctrine of Monophysitism was not unified but varied according to each region.

On the other hand, the social meaning of the Chalcedonian formula has been suggested from the point of conflict for liberty. Modern historians usually understand the doctrines of the Council not in terms of their precedents for modern political liberty, but as a product of intellectual currents particular to late Roman Christianity and the rivalry between theological schools at Alexandria (which tended toward Monophysitism and represented the East) and Antioch (which adamantly defended Christ's dual nature, and usually allied with Rome and the West). ${ }^{11}$ Rushdoony, however, suggested that Chalcedon made Western liberty possible. ${ }^{12}$ According to him, when unity and particularity (or individuality) are in their ultimate source transcendental and firmly grounded in the triune God, man's realization of unity and individuality is freed from the oppressive presence of the state as the realized order.

M. Worthen says that Rushdoony's reading is closer to the understanding of the fourth and fifth centuries, when Christology was not an abstruse debate among churchmen, but a matter of immediate political concern. ${ }^{13}$ That is, one's view of Christ shaped one's views of Caesar. For example, during the earlier Nicene controversies, Arian Christians, who viewed Christ as a lesser creature, often embraced a similar view of the emperor. Unsurprisingly, many $4^{\text {th }}$ and $5^{\text {th }}$ century Roman emperors favored Arianism. Catholics who rejected the subordination of the Son also resisted to the imperial domination of the Church. Only a fully understood Trinitarianism proved itself capable of resisting the exploitation of Christian monotheism as a means of sanctioning political unity and social cohesion. ${ }^{14}$

To the contrary, Easterners, allied with Alexandria who preferred the Monophysite view that the divine obliterated His humanity, blurred the distinction between the divine and human. According to Tillich, ${ }^{15}$ Antioch

11. M. Worthen, "The Chalcedon problem: Rousas John Rushdoony and the origins of Christian Reconstrucionism," Church History 77, no.2 (June, 2008): 408.

12. R.J. Rushdoony, The Foundations of Social Order: Studies in the Creeds and Councils of the Early Church (California: Ross House Books, 1968), 78f. According to Rushdoony, Americans have forgotten the lesson of Chalcedon: the fundamental division of the divine from the human, as well as their status as mere creatures and their utter dependency on a sovereign God. The State now claimed sovereignty for itself, and humans believed themselves sovereign over reality by their powers of logic and experience. Society had fatally mixed the divine with the human and set up two false idols: human reason and the State. He says, there could be no reason without God, and the modern deification of reason was an outgrowth of the "hybrid worldview" that emerged when Christians allowed themselves to be contaminated by Greek philosophy, Cartesianism, rationalism, and Kantian and existential thought. In my opinion, however, such a human belief for sovereignty of the State or human reason, two false idols, does not refer only to modern Americans but those of the early Byzantine period itself, as the latter ceaselessly tended to betray the real will of God and discard utter dependency on a sovereign God, exploiting religion's dogma for their worldly profits.

13. M. Worthen, "The Chalcedon problem: Rousas John Rushdoony and the origins of Christian Reconstrucionism," Church History 77, no.2 (June, 2008): 408.

14. M. Worthen, "The Chalcedon problem: Rousas John Rushdoony and the origins of Christian Reconstrucionism," Church History 77, no.2 (June, 2008):408; G.H. Williams, "Christology and churchstate relations in the fourth century," Church History 20, no.3 (September 1951): 6.

15. P. Tillich, A History of Christian Thought: From its Judaic and Hellenistic origins to Existentialism, ed. C.E. Vraaten (N.Y.: Simon and Schuster, Inc., 1967): 85. M. Worthen, "The Chalcedon problem": 408. 
defended the church against the Monophysites for whom the human character of Christ was swallowed up in His divinity and who also gave rise to numerous magical and superstitious ideas. Thus, Antioch paved the way for the Christological emphasis of the West.

In my opinion, however, even the 'unity and particularity' of the Chalcedonian Orthodox formula as a source of Western liberty as Rushdoony suggested, when entangled in the mechanism of political power, it does not always refer to everybody's liberty, but it could degenerate into an instrument protecting the prerogatives of the privileged. Actually, it was exploited for the liberty of a privileged minority, Byzantine senatorial or provincial aristocrats or a definite group of priests of the Western Church. No matter whether it is Orthodoxy or Monophysitism, vindication of a dogma and the rejection of others as heretics or pagans would result in the forfeiture of liberty, furthering political oppression and economic exploitation of the privileged against the ruled. In this point, it seems, Orthodoxy itself is found more or less in a similar context with Monophysitism because some emperors preferred it for extending their political domination.

\section{Contrast of Liberty, Pacifism and Militarism, Bureaucratism in Polytheistic Hellenism and Monotheistic Christianity}

G. Fowden explored the confrontation of polytheism and monotheism as a fundamental explanation of the course of late antique and early medieval history in the East. ${ }^{16} \mathrm{He}$ supposed that there is a natural affinity between monotheism and political universalism (as an aspiration to dominate the known world); a unitary outlook is thought to engender a unitary polity. According to him, monotheist Christianity held great attraction for an aggressive universalist monarch such as Constantine the Great. On this point he returns to an interpretation enunciated a hundred and fifty years ago by Jacob Burckhardt. Fowden also recognized, as Burckhardt had, the potential of Christian monotheism (and Islamic later) for imperialist domination. The difference between them lies in the evaluation on Eusebius. Burdkhardt judged Constantine as essentially irreligious; he thought a pragmatic manipulator of ecclesiastical forces could be helpful to him. And he accused Eusebius of tendentiousness and mendacity in his biography of the emperor. He believed that the Church used Constantine after his death in almostthe same way Constantine had used the Church. Fowden, however, has a much greater respect for Eusebius. ${ }^{17}$

Bowestock argued against Fowden, insisting that the success of the Roman Empire for nearly three centuries - an empire that was certainly the most

16. G. Fowden, Empire to Commonwealth: Consequences of Monotheism in Late Antiquity (Princeton: Princeton U.P., 1993).

17. G.W. Bowerstock, "Polytheism and Monotheism in Arabia and the Three Palestines," Dumbarton Oaks Papers 51 (1997): 2. Eusebius, a bishop at Caesarea-by-the-Sea in Palestine, rarely saw Constantine, yet considered him a precious resource for the growing Church. 
extensive, coherent, and enduring of any in antiquity - constitutes proof that polytheism was perfectly capable of sustaining political universalism. ${ }^{18}$ Alexander the Great, too, showed that Greek polytheism could, to some extent, support a concept of world domination through shared Hellenism. Actually, the Romans also had an unmistakable equivalent to the unifying single god of the Christians: this was the cult of emperors, living and dead, thing which was as Bowerstock says, rightly recognized by Fowden as the basis for polytheist universalism in the Roman era. It was such a potent force in consolidating power.

Bowerstock pointed out that the Jews do not figure much in either Burckhardt's or Fowden's analysis. Monotheism was not struggling against polytheism, neither heresy against orthodoxy, nor tribe against tribe. ${ }^{19}$ The struggles appear within the community of Semitic monotheists, for example, between Jews and Samaritans, and between Jews and Christians. According to Bowerstock, the Monotheist faith and polytheist pleasure were by no means incompatible in the real world. For example, the festival called Maioumas ${ }^{20}$ survived at Constantinople into the reign of Leo IV in the $8^{\text {th }}$ Century as a celebration in the baths of Sophianae. ${ }^{21}$ Moreover, the Christian habit of deposing heretics and non-Christians of whatever persuasion into a general category of pagans and outcasts led to a strange but powerful conjunction of non-Christian monotheists, including Jews and their traditional enemies the Samaritans, with all kinds of polytheists. To this diverse assemblage the masses of benevolent Christians, who savored pagan practices to a degree that they could not have judged them particularly harmful to their souls, were added.

In my opinion, however, if Byzantine monotheism contributed to political universalism as Fowden insists, it should be considered, not only in its theological dimension, but also in its political and social context: monotheism was exploited for justifying uniform bureaucratic hierarchy or militaristic conquest. If monotheism is not combined with political or military initiatives, it does not necessarily lead to a unitary polity, but, as Bowerstock discussed, to numerous, separate aggregations of monotheists. The critical criterion for this comparison is not whether it is monotheism or polytheism, but whether it is pacific, tolerant universalism or military or exclusive universalism. Even within the Byzantine authority itself, the method of realizing Christian

18. G.W. Bowerstock, "Polytheism and Monotheism in Arabia and the Three Palestines". Dumbarton Oaks Papers 51 (1997): 2.

19. G.W. Bowerstock, "Polytheism and Monotheism in Arabia and the Three Palestines," Dumbarton Oaks Papers 51 (1997): 5.

20. G.W. Bowerstock, "Polytheism and Monotheism in Arabia and the Three Palestines," Dumbarton Oaks Papers 51 (1997): 6. Maioumas was a kind of fesival. Its name derived from the Semitic work for water (may). It attracted enthusiastic crowds in the cities of the Near East and Anatolia. Gaza, with a port of the same name and a lively pagan cult of Marnas, is a prime candidate for the celebration of the Maioumas. Recently, a vast shallow pool at Aphrodisias in Caria was discovered together with an inscription honoring a leader of the festival called Maioumarch.

21. Theophanes, Chronographia, 1.451.25-27. [ed. C. de Boor, 2 vols. (Leipzig: Teubner, 1883-1885/ repr. Hildesheim. 1963]. 
universalism shows diversity, unfolding a striking contrast between two contradictive universalisms.

These kinds of contradictory standpoints are disclosed in contemporary discussions. In the fourth century, Eusebius developed the concept of a 'king like God' for Constantine the Great, which has its origin in the HellenisticRoman tradition on the one hand, and was influenced by Christianity on the other. He says that God allowed Constantine to be the Great monarch and a winner against a tyrannical race (tyranniko genos). ${ }^{22}$ Also that God made the emperor the wisest herald who conveyed with the loudest voice the immutable reverence for God, and was apparently the teacher who instructed piety to all the races. ${ }^{23}$ Thus, the emperor brought peace to the world and faith to God. ${ }^{24}$

Eusebius $^{25}$ disparaged (Elder) Cyrus II, the king of Persia (559 529), and Alexander (4th C. B.C.) in comparison with Constantine the Great. He spoke ill of Cyrus' military, spiritual and administrative competence. And he denounced Alexander as a destroyer, drunkard, killer of the youth, a baseless vulgar person, a travel-maniac, and criticized his military imperialism which had resulted in negative consequences. Eusebius added that fate, by taking away Alexander's life, kept humans from extermination. ${ }^{26}$ This appraisal of Eusebius against Alexander was contrary to the prevailing commonsense of the Byzantine world in those days. ${ }^{27}$ Eusebius said, 'Our king (Constantine the Great) arises where the Macedonians come to an end', and Constantine the Great was described as subjugating the world peacefully, ${ }^{28}$ and the people of the Roman Empire should be humanely ruled. ${ }^{29}$

About two centuries later, under the reign of Justinian there were two contradictory definitions regarding the emperor's standpoint relating to Christian universalism. Agapetus, Deacon and Procopius advocated Christianity for the value of philanthropy and its tolerance of the pagans. Romanus Melodus and Cosmas Indicopleustes supported the exclusive privileges of the upper classes.

Agapetus Deacon said in the <Mirror of Emperor>, discussing the emperor's power in worldwide dimensions, that a king as a ruler has to govern orderly with scrupulous precaution, prevent disorder and keep the ship of world

22. Eusebius, Vita Constantini (Bios Konstantinou), 1.5.1: 2.19.2.

23. Eusebius, Vita Constantini, 1.4.

24. Eusebius, Vita Constantini, 2.56.1.

25. Eusebius, Vita Constantini, 1.7.1.

26. Eusebius, Vita Constantini, 1.7.2. In the same Hebrew tradition, there have been different evaluations about Alexander. The negative evaluation against Alexander is found already in Daniel and Maccabees I of the Old Testament. For the positive tradition as the model of a ruler, cf. Maria KampouriBampoukou, "To 'Mythistorima tou Alexandrou' i o Pseudokallisthenis kai oi apeikoniseis tou se byzantina cheirographa," in Aphieroma sti mnimi tou Sotiri Kissa [Elliniki Etaireia Slabikon Meleton] (Thessaloniki: University Studio Press, 2002), 116.

27. Actually, Alexander was decorated as an ideal ruler, and a saint of Christian belief, as well as a ruler of courage and justice conquering both East and the West, an excellent Christian of philanthropy and goodness. Cf. Maria Kampouri-Bampoukou, "To 'Mythistorima tou Alexandrou' i o Pseudokallisthenis", 101-133; Pseudokallisthenes, Mythistorema Alexandrou (Five different legends survived in the same author's name; M. Kampouri-Bampoukou, "To 'Mythistorima tou Alexandrou' i o Pseudokallisthenis, " 107,108, n.16).

28. Eusebius, Vita Constantini, 1.8.1-3.

29. Eusebius, Vita Constantini, I.25.1. 
government from falling into the current of unlawfulness. ${ }^{30}$ And he designated as the king's qualifications justice (dikaiosyne), good will (eunoia), philanthropy (philanthropia), piety (eusebeia), ${ }^{31}$ calmness, obedience, benevolence for the public, and imitation of God, ${ }^{32}$ and added the Christian virtues that the love of wisdom is the base of philosophy, and the devotion to God is the foundation of wisdom. ${ }^{33}$ And Procopius denounced Justinian for being too addicted to Christianity ${ }^{34}$ and his oppression against heretics as well as Greek pagans, ${ }^{35}$ and cautioned that the emperor's blind belief in Christ might injure his subjects. ${ }^{36}$

Romanus, the highest poet, however, thoroughly rejecting classic pagan education, defined the function of the emperor as closely related with God. ${ }^{37}$ On the one hand, the emperor is a representative of not only the people but also of God on the earth. On the other, Romanus says, the emperor is connected with citizens and priests, and Christ protects the city, church, and officials (archontes). Here the citizens, the priests as well as the city and church do not refer to the universal but to the exclusive closed groups of people.

On the other hand, religious exclusivism and militarism were not an exclusive monopoly of the authority of the Byzantine Empire, but they could appear in every corner of the world. A militant monk, Barsauma the Monophysite from Mesopotamia made an attack to destroy both synagogues and temples, to persecute Jews and polytheists alike. ${ }^{38}$ Maybe, as Bowerstock says, these people were all regarded as pagans by such a fanatic Monophysite Christian. But the more important point is that at first the government at Constantinople recognized that Barsauma's zeal would do no good to the cause of prudent administration. The legislation of 423 protected the Jews from pillaging and destruction. ${ }^{39}$ Later, however, a novella of 438 (or 439) by anti-

\footnotetext{
30. Agapetus Deakon, Expositio de Capitulos Admonitorios [Ekthesis], 1.

31. Agapetus Deakon, Expositio, 26:28:34.

32. Agapetus Deakon, Expositio, 2:5:8:19:21:37:46.

33. Agapetus Deakon, Expositio, 36.

34. Procopius, De Bellis [Hyper ton Polemon], 7.35.11. Cf. 7.32.9.

35. Procopius, Historia Arcana [Anekdota]. 11.14-33.

36. Procopius, Historia Arcana, 13. 4-11.
}

37. (Sanctus) Romanus Melodus, Melodi Cantica : Cantica Genuina, ed. Paul Maas and C. A. Trypanis (Oxford, 1997). Cf. The Christian God's favor refers to exclusive privilege in economic fields, too. According to Cosmas Indicopleustes (Christiana Topographia, 1.2.77), the Byzantine Empire transcended Persia as well as other states, and its currency in power of purchase and circulation proved God's favor bestowed on the Christian Romans. The currency of Byzantium, he says, was circulating in every corner of the world, and such a kind of currency was found nowhere else, so that every person and every king was filled with exclamation. Procopius (De Bellis, 7.33.6. Cf. Zonaras, Epitome Historiarum, 3.230) proved the fact that alien gold coins without the Byzantine emperor's portrait did not circulate. The monopoly of the Byzantine Empire held on till the Arabs succeeded them. From the second half of the 7th century when the Arabs advanced, the Byzantines and the Arabs did not interchange currency [cf. Theophanes, Chronographia, 254 (302-303), Carl de Boor ed., p.466, CSBH)], as each of them did not want to recognize the other's authority.

38. F. Nau, "Résumé de Monographies syriaques [Summary Syriac Monographs], "Revue de l'Orient Chretien, 2nd ed. ser., 8, no.18 (1913): 382. G.W. Bowerstock, "Polytheism and Monotheism in Arabia and the Three Palestines," 4.

39. Corpus Theodosianus, 16.10.24. Cf. G.W. Bowerstock, "Polytheism and Monotheism in Arabia and the Three Palestines", 4. 
Semites (Jews) marked an unfortunate regression toward his militant intolerance. $^{40}$

\section{Inner Discord of the Byzantine Empire referring to Monophysitism in the $5^{\text {th }}$ and $6^{\text {th }}$ Centuries}

Monophysitism held its ground even after the Council of Chalcedon. The central authorities of the Byzantine Empire were not strong enough to enforce the Chalcedonian doctrine in the Eastern countries, but tried to restrict the activities of the Monophysites. One measure was taken against the monks. Unprecedentedly, the emperor Zenon issued the order that the monks should be subordinated to the supervision of the bishops, and were prohibited to move freely about. ${ }^{41}$ The Monophysites detested the aristocratic Senators of Constantinople, who emerged as privileged after the council of Chalcedon, rising above the control of the higher priests, although they were still in alliance them. Standing against the restrictions the monks sided with the people, so that it became more difficult to stamp out the Monophysites.

The discord between the Orthodoxy and Monophysitism also unfolded in the capital, Constantinople, as there were emperors who vindicated Monophysitism, and also senatorial aristocrats opposed to it. Furthermore, in the capital, Constantinople, as well as in several Eastern countries, discord developed between the higher priests and the people on the side of Monophysitism.

For example, when a new episcopate was created in Jerusalem in 451, the same year the Council of Chalcedon was held, the protest by the Monophysites was so severe that a lot of monks were executed. ${ }^{42}$ The situation in Egypt was more critical, as in 457 the people marched along the streets with the corpse of Proterios, the bishop of the Orthodox Church, whom they had killed. Also Leon I, the Byzantine emperor, when he banished the Monophysite bishop, Timotheos Elouros, was confronted with a demonstration by the Eastern people and priests (458).

Moreover, in Antioch where a large part of the community was Monophysites, the restrictions against the monks were not applied. At least by 471, the people and the monks elected Petros Gnapheus as archbishop, and the latter was banished to Egypt (the desert Thebaida where Nestorios had been banished in earlier days). It was about the same time when Timotheos Elouros, a Monophysite, was expelled to Cherson (the Cream Peninsula), as well. The

40. G. Stemberger, Jews and Christians in the Holy Land: Palestine in the Fourth Century, Trans. by Ruth Tuschling (Einburgh: T\&T Clark Ltd., 2000) [Juden und Christen im Heiligen Land (München, Verlag C.H. Beck, 1987]: 311; G.W. Bowerstock, "Polytheism and Monotheism in Arabia and the Three Palestines,"4.

41. F. Winkelmann, Die östliche Kirchen in der Epoche der christologischen Auseinandersetzungen [The eastern churches in the era of the Christological disputes] (Berlin: Kirchengeschichte in Einzeldarstellungen I, Alte Kirche und frühes Mittelalter 6, 1980), 136 [T.K. Louggis, Episkopisi Byzantinis Istorias, I (324- 1204) (Athina: Synchroni Epochi, 1998), 90].

42. T.K. Louggis, Episkopisi Byzantinis Istorias (324-1204), [Overview of Byzantine History (3241204)], I , $91 \mathrm{ff}$. The contents below whose sources were not specified based on this book. 
Byzantine emperors, Marcianos, who led the Council of Chacedon, and his successor Leon were hated by the Eastern people who suffered at the hands of the large landowners.

Afterwards, Byzantine religious politics ran in a zigzag course according to the viewpoint of each emperor. The Byzantine emperors who supported or tolerated Monophysites incurred the enmity of the senatorial aristocrats of Constantinople, and moreover of the Roman Pope.

In 468 Leon I, successor of Marcianos, passed a law that qualified the Orthodox Christians only for administrative and judicial offices. ${ }^{43}$ It is shown that he tried to command the Empire by a uniform bureaucratic system. The political bureaucracy corresponds to the hierarchy of the Orthodox Church. Afterwards, however, the emperors, Zenon and Basilicus, former generals, supported Monophysitism.

As Leon I died in 474, his immature grandson Leon II ascended to the throne with his father Zenon as co-emperor. Leon II, however, had a doubtful death in the September of the same year, and Zenon became sole emperor. Zenon maintained friendly relations with the Monophysites, as he was well versed on the Eastern people, having performed duties in Antiochia as a general of Anatolia.

On the other hand, Basilicus, being of aristocratic origin, dethroning Emperor Zenon(Jan. 475) acceded himself to the throne, after he had failed in his expedition to the land occupied by the Goths to enthrone Julius Nepotas as the Western emperor. However, he took the same standpoint as Zenon in supporting Monophysitism. And, in these days the archbishops of the Monophysites, Timotheos Elouros of Alexandria (d. 477) and Petrus Gnapheus of Antiochia returned, being redeemed from expulsion. Notwithstanding the opposition of the Patriarch of Constantinople, Basilicus announced the 'Circular (Egkyklio)' which refused the decision of the Fourth Ecumenical Council of Chalcedon. This measure curried favor with the Eastern people, but incurred the enmity of the senatorial aristocrats of Constantinople. ${ }^{44}$

Zenon, who had sought safety by going to his hometown of Isauria, sought to be reinstalled on the throne with the help of some officers of high rank (Aug. 476). He concluded a treaty with the Barbarians on the one hand, and was tolerant toward the archbishops of Alexandria and Antiochia, who were supported by the people, on the other. ${ }^{45}$ Standing face to face with the aristocrats of the capital, Zenon enacted a law of the following purport ${ }^{46}$ : as the existing Senate, ignoring the people's will, persisted in the appointment of an

43. Idem, 92.

44. Idem, 93.

45. Zenon's standpoint incited the senators' anger and the senatorial aristocrats tried to bring an Orthodox aristocrat, Marcianus, forward as emperor. Marcianus was to the aristocrats' taste as he was a descendant of the Anatolian emperor, Marcianus, as well as the Western Roman emperor, Anthemius (467- 472). Zenon cut off their attempt, and also dispersed the attempt restoring the throne of Western Rome to Julius Nepotas who was then in Dalmatia. Nepotas was murdered in 480, a murder in which Zenon was involved, and he had Dalmatia incorporated to the province of Italy in 481. Cf. T.K. Louggis, Episkopisi Byzantinis Istorias (324-1204), [Overview of Byzantine History (324-1204)], I (324-1204), 93f.

46. Cf. T.K. Louggis, Episkopisi Byzantinis Istorias (324-1204, [Overview of Byzantine History (324-1204)], I,94. 
Orthodox Christian as the archbishop of Alexandria, the Senate will consist of the so called illustrated (viri illustres) exclusively. For this, the Pope of Rome, Simplicius (468 483), followed the same line as the aristocrats of Constantinople in denouncing Zenon as ignoring the West.

Consequently, in 482 Zenon (474 475, 476 491) made a concession promising the appointment of an Orthodox Christian as the successor of the archbishop of Alexandria. Concomitantly, however, he promulgated the "Unification (Enotikon) [482]" refuting the decision of the Council of Chalcedon, and prohibited the polemic of the religious doctrine, trying to mediate between the Orthodox and the Monophysites. ${ }^{47}$ The Eastern people, regarding themselves liberated from the restrictions of the Council of Chalcedon, elected the Monophysite, Petros Mongos, to be archbishop. The Orthodox aristocrats in Constantinople, however, allied with the Roman Pope, Simplicius, to nullify Zenon's Unification.

The emperor Anastasios (491 518) also confronted the Orthodox Christians. On the occasion of the uprising of the Orthodox in 495, he deposed the Orthodox Patriarch Euphemios (Euthymios), while he tolerated the activities of the Eastern provinces where the order of Unification prevailed. ${ }^{48}$ However, as Philoxenos, the Monophysite archbishop of Hierapolis, widened his influence, the senatorial aristocrats reproached the emperor as a heretic in 499. And, when under the protection of Anastasios, the Monophysite Severus (512 518, d. 538) was elected as the new archbishop of Antiochia, then, it is said, the Orthodox in Constantinople caused a riot in order to kill lots of Monophysites. ${ }^{49}$

\section{Coexistence and Discord between Orthodoxy and Monophysitism in the Reign of Justinian the Great}

It was the emperor Justinian I the Great who initiated the concept that the greatest gift granted by God who loves human beings is sacred (hierosyne) and political (basileia) power. ${ }^{50}$ It has been discussed that the so called Caesaropapism reached the point of apogee, quintessence, under the reign of Justinian the Great, as the church came somewhat fully to be subordinated to the worldly state. ${ }^{51}$

47. Evagrius Scholasticus, Historia Ecclesiastica, "Enotikon tou Zenonos", 3, 14, [Patrologia Graeca 86$]$.

48. Theophanes, Chronographia, 121 (p.140, ed. Carl de Boor/ p.217 CSBH 43).

49. (Ioannes) Malalas, Chronographia, 408.

50. Justinianus, Novellae, 6 (Prooimion).

51. Alexis G.K. Sabbidis, Meletimata Bizantinis, Mesaionikis, kai Islamikis Istorias [Studies of Byzantin, Medieval and Islamic History] (Pharsala: Herodotos, 1997), 19. The word "Caesaropapism" was used in the 19th century by a German Historian, J. Hergenröther [Handbuch der allgemeinen Kirchengeschichte, 3 vols (Freiburg i. B.: Herder, 1876-1880); cf. A. Sabbidis, ibid. 17.]. Caesaropapism is an idea that combines the power of secular government with the religious power, or makes it superior to the spiritual authority of the Church. 
In the introduction of Novellae by Justinian I, the phrases frequently refer to worldly power which has been bestowed by God. ${ }^{52}$ The Christian Ideology of world domination described in Novellae (109: prooimion) referred to all people including pagans, and the tradition of this so called universal Christian 'imperialism' originates in the Bible. ${ }^{53}$ The fact that Christianity was exploited as a means of governing is demonstrated in the Justinian Code of Law. ${ }^{54}$ Cosmas Indicopleusteus identified kingship with the competence of Christ, and it was exploited to justify the re-conquest of Justinian I. ${ }^{55}$

The coexistence of two opposite tendencies, however, coercion by arms and power, and striving for peace by cooperation on the other, proves itself in the Code of Justinian the Great. In the Codex the ideology of the Roman (Byzantine) emperor for world domination is represented. It says that the Empire is based on two roots, that is, arms and laws, and with these the world domination of the Roman Empire could be forever sustained over all races. ${ }^{56}$ In Novellae, it is stated that for the world domination of the Empire, churches and the state should be in close cooperation with each other. ${ }^{57}$

Justinian's policy against the Monophysites of Egypt seems to have been founded on this kind of universalism. In 541 the bishop of Alexandria, Theodosius who was a Jacobite and the Monophysites of Syria, were summoned to Constantinople and forced to convert to Orthodoxy. But Theodosius denied the request and was expelled with his followers. When Justinian appointed an Orthodox bishop to Egypt where Monophysitism held the upper hand, a dispute took place. Furthermore, the efforts of Justinian to establish his authority in Nubia were efficiently actualized with the destroying of the pagan temples on the island of Phyles. He ordered the general Narses to convert the pagan temples to Christian churches. This policy denotes the disintegration of an existing independent, closed Nubian society, and the establishment of a new social, political system. ${ }^{58}$ Justinian's military expansion was applied also to Ethiopia-Omeritoi, Cafcas and the Cream peninsula.

52. Justinianus, Novellae, 148 (prooimion) [The words of Justinus II]: 16 (prooimion), 164 (prooimion) [The words of Emperor Tiberius].

53. New Testament [Kaine Diatheke], Matthew, 28, 19-20; Mark, 16.15; Luke, 24.47.

54. Justinianus, Novellae, 37 (De Africana Ecclesia, 535).

55. Cosmas Indicopleustes, Christianike Topographia, I.2.70. According to Cosmas, Daniel foretold that all the other empires, including Babylonia, Media, Persia and Macedonia would fall by the Advent of Christ. S. Patoura-Spanou, Christianismos kai pagkosmiotita sto proimo, 94, 96.

56. Justinianus, Digesta, 2.1

57. Justinianus, Novellae, 6. This decree was promulgated in April 17, 535. Cf. For reference it is stated in the Codex, <[Eisagoge e] Epanagoge, 2.8 (Appeal to a Higher Court)>, of Leon III of the Macedonian Dynasty that both Emperor and Pope are like as to the body and soul of a man respectively, and the two entities should cooperate with each other to promote power, peace and the prosperity of the Empire.

58. In the earlier time even when the Orthodox prevailed in the Byzantine Empire, the missionaries of various sects were sent to Nubia where there was yet no religious discord and Monophysitism held the upper hand. On the other hand, already in the 6th century, the three kingdoms of Nubia, on the model of the Byzantine Empire, were equipped with the state's organization and the hierarchy of the church. Justinian I made an effort to expand the influence of the Eastern Orthodox Church, by interfering with the election of these three kings of Nubia. Cf. S. Patoura-Spanou, Christianismos kai pagkosmiotita sto proimo Byzantio, 343f., 394. 
However, the real situation did not develop according to the wishes of Justinian. Justinian's empress, Theodora, who came from Africa, sent Monophysite missionaries, Theodosius who had been ousted and Julianus, to propagate Christianity to Nubia where Monophysitism prevailed. ${ }^{59}$ Ioannes of Ephesus gives evidence that both contrary missionaries were dispatched by the Byzantine authority to Nubia. Ioannes of Ephesus himself as a Monophysite was inclined to speak highly of the Monophsite missionary sent by the empress rather than of the Orthodox missionary sent by Justinian.

Procopius did not criticize regarding the fact that the empress Theodora dispatched Monophysite missionaries, and at the same time he was not surprised that Justinian sent those of the Orthodox. Referring to Procopius' tolerance, Patoura-Spanou commented that the Byzantine Empire took advantage of whichever sect or doctrine of Christianity, Orthodoxy or Monophysitism or Arianism, etc. for expanding its influence. ${ }^{60}$ Julianus, Theodosius and Theodorus, the Monophysite bishop of Phyles, however, made an effort to keep their own faith despite the intervention of the Byzantine Empire. Concomitantly, according to the report of Ioannes Ephesus, Justinian accepted the will of Theodora to send gifts as well as missionaries to Thebe as well as Upper Egypt. ${ }^{61}$

Inconsistency is shown in Justinian's religious policy regarding the Monophysites in Syria, also. Syrian Christianity reveals a powerful spirit of self-consciousness for independence. ${ }^{62}$ Then, in the fourth and fifth century, there was the spectacular growth of monasticism in Syria and Mesopotamia. The Syrian Orient, where abuse on the part of the administration was reckless and the peasantry particularly suffered very hard, embraced Monophysitism, and within a short time Monophysitism was no longer merely a protest against the Chalcedonians but became a developed doctrine. It was a movement with its own content and a separate church, which did not hope for anything from the Byzantine emperors nor from the Byzantine church. The critical moment of this advance was the fateful period under the Emperor Justinian. ${ }^{63}$

Already his predecessor, Emperor Justin (518-527) had condemned the Monophysite Patriarch Severus $(512-518)$ by a synod in 518. During the following year a large wave of persecution swept through the patriarchate and engulfed the monks. ${ }^{64}$ Justinian the Great (527-565), however, eased the furor and therefore a surging emotion of relief must have been felt by all the vexed monks. During his period, the foundation was laid for an indigenous law which was designed to regulate ecclesiastical practice in piety, worship, liturgy and

59. S. Patoura- Spanou, Christianismos kai pagkosmiotita sto proimo Byzantio, 343.

60. S. Patoura-Spanou, Christianismos kai pagkosmiotita sto proimo Byzantio [Christianity and Globaliy in Early Byzantium: From theory to Practice], 121.

61. Idem, 344f.

62. A. Vööbus, "The Origins of the Monophysites Church in Syria and Mesopotamia," Church History 42, no.1 (Mar. 1973), 17f.

63. Idem, 18.

64. Acta Conciliorum Oecumenicorum, ed. E. Schwartz (Berolini: Walter de Gruyter, 1914ff.), 3 , 76ff. Cf. A. Vööbus, "The Origins of the Monophysites Church in Syria and Mesopotamia," 19. 
church order. By the canons issued by Johannan of Tella, the Syrian Monophysite tradition began to take on definite form. ${ }^{65}$

During the summer of 531 the Emperor Justinian issued an order permitting the exiled monks to return. ${ }^{66}$ Near the end of the year, half a dozen bishops, also in exile, were given a royal invitation to present themselves at Constantinople. The Monophysites were allowed to disseminate their propaganda in complete freedom, and in 535 Anthimus, who had antiChalcedonian beliefs, was appointed as the new Patriarch. On top of all this, the ex-Patriarch Severus was invited to come to Constantinople, and he was received with great honor.

Before long, however, Anthimus was deposed by the intervention of the Roman Pope Agapetus. ${ }^{67}$ The submission of a confession, Chalcedonian in theology, was required, ${ }^{68}$ and Monophysite leaders were anathematized by a synod which was convened. ${ }^{69}$ Severus was thrown into prison, and later escaped by the help of the Empress Theodora. During the winter of 536/7 Patriarch Ephrem was accompanied by a detachment of soldiers ${ }^{70}$ to the East in order to ensure the submission of the Monophysites and to break their spirit. ${ }^{71}$ Johannan of Tella returned from Constantinople, and sought safety in the mountains of Shiggar. Finally he was captured, imprisoned and killed in Antioch (538).

On the other hand, in 542/3 Hrith bar Gabala, King of the Arabs, suddenly appeared in Constantinople. He was determined to create a Monophysite realm in his kingdom and demanded two or three bishops for Syria from Theodora. Thus, Patriarch Theodosius consecrated two monks, Theodorus of Arabia and Jaqob Burdana. It was Jaqob who expanded the hierarchy of the Monophysite church. $^{72}$

Justinian's religious policy against the Monophysites does not seem to have had consistency, but it alters completely on the principle of power politics. Justinian was a realist who made good use of two contradictory strategies; militaristic and religious compulsion against those whom he could control on the one hand, and reconciliation with those who were outside his influence on the other.

The dualism Justinian sought after could be shown in the differing treatments of Nestorianism between domestic and foreign religious politics. In 562 he concluded the treaty with Kosroe of Persia and its contents, according

65. A. Vööbus, "The Origins of the Monophysites Church in Syria and Mesopotamia," 20.

66. Zacharias Rhetor, Historia Ecclesiastica, II, 6.2,p.82 [CSCO (Corpus Scriptorum Christianorum Orientalium), Scriptores Syri, 39, ed. E.W. Brooks (Paris, 1924)]. Cf. A. Vööbus, "The Origins of the Monophysites Church in Syria and Mesopotamia," 21f.

67. A. Vööbus, "The Origins of the Monophysites Church in Syria and Mesopotamia," 22f.

68. Epistolae imperatorum, pontificum, aliorum, ed. O. Günther (Vindobonae, 1895-98), CSEL (Corpus Scriptorum Ecclesiasticorum Latinorum), 35, 338ff.

69. Acta Conciliorum Oecumenicorum, 3, 26ff

70. Zacharias Rhetor, Historia Ecclesiastica, II, 10.1, 174ff. Cf. A. Vööbus, "The Origins of the Monophysites Church in Syria and Mesopotamia", 23.

71. Cf. Ioannes Ephesus (John of Ephesus), Lives of the Eastern Saints, 2, ed. E.W. Brooks [Patrologia Orientalis 18 (Paris, 1924)], 607ff. Cf. A. Vööbus, "The Origins of the Monophysites Church in Syria and Mesopotamia," 23.

72. A. Vöbus, "The Origins of the Monophysites Church in Syria and Mesopotamia," 24f. 
to Menandros, were: Persian Nestorian Christians were free to build churches, chant, celebrate festivals to commemorate the saints; not be coerced by Median art of divination or God's order, and to perform funerals following the Christian way. ${ }^{73}$ To grant liberty of religion to the Persian Christians was maybe the reconciliatory diplomatic outcome of the Byzantine Empire. To concede the liberty of faith to the Persian Christians over whom the Nestorians prevailed shows the universal standpoint of the Byzantine emperor. However, this context is in sharp contrast to the severe treatment of the interior Nestorians. ${ }^{74}$

\section{Reaction of the Byzantine Aristocrats and the Roman Pope to the Emperors' Support of Monophysitism}

Some Emperors of the early Byzantine period supported or tolerated Monophysites, but the discord did not run to an extreme, and a compromise was made more or less between the contending parties. For example, as introduced above, emperor Zenon appointed an Orthodox Christian for the archbishop of Alexandria, and concurrently he promulgated the 'Unification (Enotikon) [482]' to prohibit arguments over religious doctrine. ${ }^{75}$ The Orthodox aristocrats in Constantinople, however, allied with the Roman Pope, Simplicius, to nullify Zenon's Unification. Simplicius, in cooperation with the Orthodox and the monks under the supervision of the aristocrats in Constantinople, denounced Zenon and Makakios (472 488), the Patriarch of Constantinople, as heretics. ${ }^{76}$ And, when Felix (483 492), who succeeded Simplicius as the Pope of Rome, opposed the Unification, the discord came to the fore for the first time explicitly between the Eastern and Western Churches.

As the emperor Anastasios (491 518) was also inclined towards the Monophysites, he confronted the opposition of the Roman Pope Symmachus (499 514) who forced him to condemn the Monophysites. Anastasios (d. 518) had to also compete with the new Orthodox Roman Pope, Ormisdas (514 523).

Successively, in the second year (March 28, 519) of the reign of Justin (518 527), Ormisdas, the so called most sacred Pope of the Roman (Apostolic) Orthodox Church (Apostolike Edra tes Romes he Orthodoxia) ${ }^{177}$ promulgated the "Announcement of Ormisdas". Here all the Greeks of the Eastern Orthodox

73. Menandros, Historia, 364 [CSBH, ed. I. Bekker \& B.G. Niebuhr].

74. Cf. A. Guillaumont, "Justinien et l'eglise de Perse," Dumbarton Oaks Papers 23-24 (1969-1970), 49-50.

75. Evagrius Scholasticus, Historia Ecclesiastica, "Enotikon tou Zenonos", 3,14, [Patrologia Graeca 86].

76. Cf. After Phelix (483-492) succeeded Simplicius, the antagonism between Rome and Constantinople continued till Isauros Illos rose in revolt in 484, a revolt which Zenon put down. He died in 491.

77. Cf. Ormisdas declared that the Roman Orthodox Church sustained itself without mutation, based on Jesus' statement in Matthew 16:18 (I also say to you, that you are Peter, and on this rock [cf. Peter refers to rock (petra)] I will build my assembly). 
Church as well those in Constantinople, signed. Its purport is to confirm the decision of the Third Ecumenical Council of Ephesos which defined the Nestorians as heretics, and as well that of the Fourth Ecumenical Council of Chalcedon to reproach Eutyches, the founder of Monophysitism. Thus, the order of Unification of the Emperor Zenon was annulled, and the names of the Monophysites were deleted from the list of priests of the Church of Constantinople. With the Announcement of Ormisdas, the relationship between the Eastern and Western Orthodox Churches was promoted as being friendly, but the Eastern provinces were alienated from them.

Contrary to Justin, Justinian the Great (527-565) tried to compromise with the Monophysites. During the summer of 531 the Emperor Justinian issued an order permitting the exiled monks to return, and the Monophysites were allowed to disseminate their propaganda in complete freedom. In 535 Anthimus who had anti-Chalcedonian beliefs was appointed as the new Patriarch. Before long, however, Pope Agapetus personally took matters into his own hands. Arriving in Constantinople in 536, he intervened in ecclesiastical matters, and Justinian complied with the wishes of Agapetos in every respect, indeed to such a point that the throne itself suffered humiliation. Anthimus was deposed by the intervention of the Pope. ${ }^{78}$ The submission of a confession, Chalcedonian in theology, was required, ${ }^{79}$ and Monophysite leaders were anathematized.

In the reign of Justinan, the discord was not revealed outwardly between the Eastern and Western Orthodox Churches, as he formerly held somewhat of a halfway position between both contending parties. However, in the end he turned towards the Orthodox.

Afterwards, however, Byzantine emperors did not give up their affection towards Monophysitism, which developed into "Monotheletism" in the 7th century. In 638 the Emperor Heraclius issued the "Report (Ekthesis)" in order to reconcile the Orthodox with Monophysites. He made a vain effort to prevent the secession of the Eastern provinces, which were to surrender to the Arabs. ${ }^{80}$

At the time of the reaction of the Roman Pope, Martinus I, and Maximus, Homologetes of Africa to Monotheletism, the Emperor Constance II announced "Formula (Typos)" in 648, to forbid argument over the Will (Function) of Divinity, whether it is one or two. However, the 6th Ecumenical Council of Constantinople (680 681), which was summoned by the emperor Constantinus Pogonatus, denounced Monotheletism as a heresy, and reconfirmed the decision of the Council of Chalcedon, that the Christ consists of two properties, that is, two Wills and two functions of Humanity and Divinity, which are unmixed but indivisible and without contradiction to each other, being stable and proportionate.

78. A. Vööbus, "The Origins of the Monophysites Church in Syria and Mesopotamia," $22 \mathrm{f}$.

79. Epistolae imperatorum, pontificum, aliorum, ed. O. Günther (Vindobonae, 1895-98), CSEL 35, 338ff.

80. Chagyu Kim, "La loi impériale et la déviance papale: recherche sur les relations entre la cour impériale byzantine et la papauté romaine (Ive-Xle siècles) [The imperial law and papal deviance: Relations between research Byzantine imperial court and the Roman Papacy (IveXle century)]," Diss., Ecole des hautes études en sciences sociales (1994). 


\section{Conclusion}

Eutychianism/Monophysitism appeared to spread rapidly in the $5^{\text {th }}$ Century in the Middle-Eastern area including Egypt, Palestine, Syria, Armenia, and by the sixth century under the reign of Justinian the Great, the Monophysites managed to arrange the canons and hierarchy of priests and churches.

After it was denounced by the $4^{\text {th }}$ Ecumenical Council of Chalcedon as a heresy, some of the Byzantine emperors still tried to reconcile Orthodoxy to Monophysitism. The senatorial and provincial aristocrats or privileged priests who advocated Orthodoxy resisted the emperors who supported Monophysitism. And the Popes of the Western Church supported Orthodoxy in alliance with Byzantine senatorial aristocrats. Even in cases where Monophysitism was tolerated by the Byzantine emperors, their purpose was never to allow the liberty of religion, but to take advantage of it politically.

Rushdoony suggested that the Chalcedonian formula made Western liberty possible. According to him, when unity and particularity (or individuality) are in their ultimate source transcendental and firmly grounded in the triune God, man's realization of unity and individuality is freed from the oppressive presence of the state as the realized order.

In my opinion, however, even the 'unity and particularity' of the Chalcedonian Orthodox formula as a source of Western liberty as Rushdoony suggested, when it entangled in a political game of power, it does not always refer to everybody's liberty, but it could degenerate into an instrument protecting the prerogatives of the privileged. Actually, it was exploited for the liberty of a privileged minority, Byzantine senatorial or provincial aristocrats or definite group of priests of the Western Church. No matter whether it is Orthodoxy or Monophysitism, vindication of a dogma and rejection of others as heretics or pagans would result in forfeiture of liberty, furthering political oppression and economic exploitation of the privileged against the ruled. In this point, it seems, Orthodoxy itself is found in a similar context with Monophysitism, such that some emperors preferred it for extending political domination.

The ecumenical Christian ideal of Eusebius refers to the evangelism of the whole world including the pagans and heretics. Christian universalism does not necessarily premise a conflict with pagans or persecution against the heretics, but it could tolerate both of them forwarding peace and philanthropy. However, the so called universalism which was exploited by some of the Byzantine emperors or most senatorial aristocrats refers to the enforcement of their own religious dogma; the former preferred Monophysitism for consolidating autocratic imperial power based on militaristic conquest, and the latter tended to prefer the Chalcedonian formula for securing their privileged hierarchy as well as decentralized liberty against an emperors' despotism.

Enforcing whichever kind of religious dogma itself denotes the degeneration of the Byzantine Society from a more open, amicable one, to an exclusive, privileged one. It is proved not only in the development of the 
hierarchic bureaucracy of the Byzantine Empire as well as the Christian church, but also in the emperors' worldly ambition for political and military expansion.

The enforcement of the religious dogma which advanced in company with the intensification of political oppression resulted in the augmentation of the complaints of each level of subjects of the provinces. On the one hand, the Orthodox archbishop of Jerusalem, Sophronius, who resisted the Monophysitism which was enforced by despotic Byzantine emperors, surrendered to the Arabs. On the other, the Eastern common people complained against the severe tax burden imposed by the authority of the Byzantine Empire or its representatives in the provinces. The situation got worse when Persia retreated from Syria, Palestine and Egypt, which came under the command of the Byzantine Empire. Bar Ebraios, the Eastern Chronicler, referring to the conquest of the Arabs, said that in the period of the Heraclian Dynasty the descendants of Ismail (the Arabs) liberated us from the evil hands of Hellenes according to the Will of God. And the contemporary Muslim historian S. Bryonis also said that hard taxes were imposed in the regions which were conquered by the Byzantine Empire. ${ }^{81}$ The heavy tax burden as well as the coercion of religious dogma led the Oriental Monophysites to surrender to the invading Muslims.

In conclusion, regardless of if it was Orthodoxy or Monophysitism, exclusive dogmatism contributed to the interests of either the prerogatives of aristocrats or the emperor's dictatorial domination. Contrary to religious exclusivism, there was a Christianity which was more universal and openminded, not only towards heretics but even to the pagans.

\section{Glossary of Terms}

Apollinarism: Apollinarius taught that Jesus was fully God, but that he was not fully human because God's spirit displaced the human spirit that existed. This was rejected as a heresy by the $1^{\text {st }}$ Council of Constantinople (381), on the basis of compromising the duality of Christ's nature that $\mathrm{He}$ is both fully man and fully God.

Arianism: Arianism purported that Jesus Christ was not God, that He was a created being. Furthermore, Jesus was the very first creation, and all other creation was created by Him. It was denounced as a heresy by the $1^{\text {st }}$ Ecumenical Council of Nicea (325) under Constantine the Great, and later again by the $1^{\text {st }}$ Council of Constantinople.

Calcedonian Orthodox or Calcedonian formula: The $4^{\text {th }}$ Ecumenical Council of Chalcedon (431) upheld Orthodoxy that Christ has two distinct natures simultaneously, a full human nature and a full God nature. Two natures, united,

${ }^{81}$ Cf. T.K. Louggis, Episkopisi Byzantinis Istorias (324- 1204) [Overview of Byzantine History (324- 1204)], I, 159. 
but distinct; one but two, unconfused, immutably, indivisibly, inseparably [united].

Eutychianism ( $\rightarrow$ Monophysitism): Eutyches espoused the idea that Christ's two natures combined and mixed with each other to create a new, third nature. It would mean that Christ is not human or God, but He is something different. Eutyches' Doctrine was rejected by the $4^{\text {th }}$ Ecumenical Council of Chalcedon (431).

Monoenergetism/ Monotheletism: Monoenergetism (one function/ act) and Monotheletism (one will/ volition) were a moderate Monophysitism which converted the dispute about nature (physis) to a dispute about the person (prosopon) of Christ, who acted according to 'theandric' (divine and human at the same time) acts and volitions. In the first half of the $7^{\text {th }}$ century, the Byzantine Emperor Heracleus supported this doctrine because he thought it would be acceptable to both Orthodox and Monophysites alike, and the Patriarch Sergius was the first to officially adopt the MonoenergeticMonotheletic views.

Monophysites: Those who espoused Monophysitism.

Monophysitism ( $\rightarrow$ Eutychianism): A heresy which was expected by Appolinarism and was similar to the principles of Eutyches. It was fostered by a reaction against Nestorianism on the one hand, and challenged the Orthodox faith of Chalcedon on the other. It taught that there were not two natures, divine and human, in Jesus but one, divine.

Monotheletism ( $\rightarrow$ Monoenergetism)

Nestorianism: It taught that Christ is made up of two distinct persons: a human and a divine, which is opposed to Orthodoxy that Christ is one person with two natures. It was denounced as a heresy by the $3^{\text {rd }}$ Ecumenical Council of Ephesus (431).

\section{Bibliography}

Primary Sources

Acta Conciliorum Oecumenicorum Edited by E. Schwartz. Berolini: Walter de Gruyter, 1914ff.

Agapetus Diakon. Expositio de Capitulos Admonitorios [Ekthesis Kephalaion Parainetikon].

Corpus Theodosianus.

Cosmas Indicopleustes. Christiana Topographia [Christianike Topographia] 
Epistolae imperatorum, pontificum, aliorum. Edited by O. Günther [Vindobonae (Vienna), 1895-98], CSEL (Corpus Scriptorum Ecclesiasticorum Latinorum), 35.

Evagrius Scholasticus. Historia Ecclesiastica, "Enotikon tou Zenonos" [Patrologia Latina, 68, 1022].

Eusebius. Vita Constantini [Bios Konstantinou].

Eusebius. Historia Ecclesiastica [Ekklesiastike Historia].

Ioannes Ephesus (John of Ephesus). Historia Ecclesiastica [Ekklesiastike Historia]. 2. Edited by E.W. Brooks [Patrologia Orientalis 18 (Paris, 1924)].

Justinianus. Digesta.

Justinianus. Novellae (Nearai).

(Ioannes) Malalas. Chronographia [Patrologia Graeca 97]. Edited by J.P. Migne.

Menandrus. Historia.

New Testament. Luke.

Mark [To Kata Markon Evangelion].

Matthew [To Kata Matthaion Evangelion].

Procopius. Historia Arcana [Anekdota].

Procopius. De Bellis [Hyper ton Polemon].

Pseudocallisthenes. Historia Alexandri [Mythistorema Alexandrou].

(Sanctus) Romanus Melodus. Melodi Cantica : Cantica Genuina. Edited by Paul Maas and C. A. Trypanis. Oxford: Clarendon Press, 1997.

Theophanes. Chronographia. Edited by C. de Boor, 2 vols. Leipzig: Teubner, 18831885/ repr. Hildesheim. 1963.

Zacharias Rhetor. Historia Ecclesiastica. Edited by E.W. Brooks. Paris, 1924. CSCO (Corpus Scriptorum Christianorum Orientalium), Scriptores Syri, 39.

(Ioannes) Zonaras. Epitome Historiarum (Epitome Historion).

Secondary Sources

Bowerstock, G.W. "Polytheism and Monotheism in Arabia and the Three Palestines."Dumbarton Oaks Papers 51 (1997): 1-10.

Fowden, G. Empire to Commonwealth: Consequences of Monotheism in Late Antiquity. Princeton: Princeton U.P., 1993.

Guillaumont, A. "Justinien et l'eglise de Perse." Dumbarton Oaks Papers 23-24 (1969-1970): 39-66.

Hergenröther, J. Handbuch der allgemeinen Kirchengeschichte [Manual of the general church history] 3 vols. Freiburg im Breisgau: Herder, 1876-1880.

Kampouri-Bampoukou, Maria. "To 'Mythistorima tou Alexandrou i o Pseudokallistheniw kai oi $\kappa \alpha$ apoikoniseis tou se byzantine cherographa," in Aphieroma sti mnimi tou Sotiri Kissa [Elliniki Etairia Slavikon Meletn]. Thessaloniki: University Studio Press, 2002.

Kim, Chagyu. "La loi impériale et la déviance papale : recherche sur les relations entre la cour impériale byzantine et la papauté romaine (IVe-Xle siècles) [The imperial law and papal deviance: Research on the relations between the Byzantine imperial court and the Roman papacy (IVe-Xle century)" Dissertation: Ecole des hautes études en sciences sociales, 1994.

Louggis, T.K. Episkopisi Byzantinis Istorias, I (324-1204). Athina: Synchroni Epochi, 1998.

Macdonald, Seumas. "The importance of the Monophysite and Nestorian controversies." Access December 1, 2014. http://bit.ly/1Lw1L0W.

Nau, F. "Résumé de Monographies syriaques [Summary Syriac Monographs]." Revue de l'Orient Chretien, 2nd ed. ser., 8, no.1 (1913): 270-276, 379-399. 
Patoura-Spanou, S. Christianismos kai pagkosmiotita sto Proimo Byzantio: Apo tin Theoria stin Praxi [Christianity and Globaliy in Early Byzantium: From theory to Practice]. Athina: Ethniko Idryma Ereunon: Instituto Byzantinon Ereunon / National Hellenic Research Foundation: Institute for Byzantine Research [Monographs 10], 2008.

Rushdoony, R.J. The Foundations of Social Order: Studies in the Creeds and Councils of the Early Church. California: Ross: House Books, 1968.

Sabbidis, Alexis G.K. Meletimata Bizantinis, Mesaionikis kai Islamikis Istorias [Studies of Byzantin, Medieval and Islamic History]. Pharsala: Herodotos, 1997.

Stemberger, G. Jews and Christians in the Holy Land: Palestine in the Fourth Century. Translated by Ruth Tuschling. Einburgh: T\&T Clark Ltd., 2000. [Juden und Christen im Heiligen Land. München: Verlag C.H. Beck, 1987].

Tillich, P. A History of Christian Thought: From its Judaic and Hellenistic origins to Existentialism. Edited by C.E. Vraaten. N.Y.: Simon and Schuster, Inc., 1967.

Vööbus, A. The Origins of the Monophysotes Church in Syria and Mesopotamia, Church History 42, no.1 (Mar. 1973): 17-26.

Wahba, Fr. Matthias F. "Monophysitism: Reconsidered." St. Antonius Coptic Orthodox Church Hayward, California, USA. Accessed December 13, 2014. http://bit.ly/1KOewTZ.

Williams, G.H. "Christology and church-state relations in the fourth century," Church History 20, no.3 (September 1951): 3-33.

Winkelmann, F. Die östliche Kirchen in der Epoche der christologischen Auseinandersetzungen [The eastern churches in the era of the Christological disputes]. Berlin: Kirchengeschichte in Einzeldarstellungen I, Alte Kirche und frühes Mittelalter 6, 1980.

Wolfson, H.A. The Philosophy of the Church Fathers. Cambridge, Mass.: Harvard U.P., 1956.

Worthen, M. "The Chalcedon problem: Rousas John Rushdoony and the origins of Christian Reconstrucionism," Church History 77, no.2 (June, 2008): 399-437. 
